ENCYCLOPEDDIE Encyclopédie berbère

BERBERE

3 | 1986

3 | Ahaggar - Alī ben Ghaniya

\title{
Āhayuf
}

\section{G. Barrère}

\section{OpenEdition}

Journals

Édition électronique

URL : http://journals.openedition.org/encyclopedieberbere/825

DOI : $10.4000 /$ encyclopedieberbere.825

ISSN : 2262-7197

\section{Éditeur}

Peeters Publishers

\section{Édition imprimée}

Date de publication : 1 juillet 1986

Pagination : 312-313

ISBN : 2-85744-260-2

ISSN : 1015-7344

\section{Référence électronique}

G. Barrère, «Āhayuf », Encyclopédie berbère [En ligne], 3 | 1986, document A108, mis en ligne le 01 décembre 2012, consulté le 12 octobre 2020. URL : http://journals.openedition.org/ encyclopedieberbere/825; DOI : https://doi.org/10.4000/encyclopedieberbere.825

Ce document a été généré automatiquement le 12 octobre 2020

(c) Tous droits réservés 


\section{Āhayuf}

\section{G. Barrère}

Le Père de Foucauld écrit āheiioūf (Dictionnaire Touareg-Français t. II p. 545].

2 Āhayuf désigne d'abord la chevelure non tressée, longue ou courte, d'un homme ou d'une femme. Plus précisément, il représente les cheveux qui recouvrent la tête, à l'état naturel, mais ne désigne pas une masse de cheveux qui en serait tombée.

3 Mais le mot signifie également «cadeau de parrainage ». La personne en l'honneur de qui on a donné le nom à un enfant, doit offrir un âhayuf à son jeune homonyme, à celui qui est en quelque sorte son « filleul ».

4 Le cadeau consiste en un vêtement, un bijou, un animal domestique, un arbre fruitier ou une somme d'argent. Il n'est accordé qu'une seule fois au cours de la vie de l'enfant, qu'il soit encore bébé ou qu'il ait atteint l'âge adulte.

5 En outre il existe deux plantes annuelles, deux espèces de paronyques, dont les noms contiennent le mot āhayuf. Ce sont:

$1^{\circ}$ āhayuf- $n$-ekli, « chevelure d'esclave », qui est une Paronychia Chlorothyrsa

$2^{\circ}$ āhayuf-n-aboyelli, mot à mot " chevelure de métis ", qui est une Paronychia Desertorum.

6 Toutes deux ont ceci de commun qu'à première vue, leur inflorescence donne assez bien l'aspect d'une chevelure crêpue.

\section{INDEX}

Mots-clés : Ethnographie, Parenté 